\title{
In Vitro Formation of Sexual Stage of Thielaviopsis paradoxa from Sugarcane in Puerto Rico
}

\author{
Lii-Jang Liu and Julia Mignucc ${ }^{\mathrm{T}}$ \\ INTRODUCTION
}

Thielaviopsis paradoxa (De Seynes) Von Höhn, is the causal agent of pineapple disease of sugarcane. It was first reported in Puerto Rico by Johnston in $1913(9) .{ }^{2}$ Cook in $1933(2,3)$ reported that this fungus caused very severe damage in Puerto Rico, especially on heavy clay soils during the cooler months of the year. Recently, a series of disease surveys were conducted over various ecological regions of Puerto Rico. Poor germination and depressed growth of canes were observed frequently in areas with poor drainage. T. paradoxa was isolated from diseased cuttings obtained from Central Cambalache-northern part, Humacao-eastern part, Central Prata-central part, and Central Mercedita-southern part, of the Island. Perithecia were formed when different isolates of the fungus were placed in culture media. The sexual stage of the fungus has not been obtained hitherto from sugarcane in vitro; the following constitutes the first description of its isolation. The purpose of this paper is to describe the morphological characteristics of the perithecia as well as their formation in vitro.

\section{REVIEW OF THE LITERATURE}

T. paradoxa first was found on pineapple in 1866 by De Seynes (6). He described the fungus under the name of Sporochisma paradoxa. Saccardo (12) in 1892 referred this species to Chalara paradoxa (De Seynes) Sace. Went (14) in 1893 reported $T$. ethaceticus as the cause of a serious disease of sugarcane in Java. Von Hohnel (18) in 1904 considered the fungus described by De Seynes and that described by Went the same organism and referred ethaceticus to synonymy. The only record on the perfect stage of paradoxa is contained in the report by Dade (4). He found a Ceratostomella on cacao husks from the Gold Coast in 1928 which he believed to be the perfect stage of this fungus. The species of Ceratostomella were transferred to Ophiostoma by Melin and Nannfeldt in 1934 (11), to Endoconidiophora by Davidson in $1935(5)$, and finally to Ceratocystis by Bakshi in 1950 (1).

\section{METHODS AND RESULTS}

Two strains of $T$. paradoxa, one light and one dark, were isoloted from diseased cuttings of sugarcane (fig. 1). The light strain was isolated from

1 Phytopathologist and Research Assistant, respectively, Agricultural Experiment Station, Mayagüez Campus, University of Puerto Rico, Río Piedras, P.R.

${ }^{2}$ Italic numbers in parentheses refer to Literature Cited, p. 100. 
P.R. 980 in the greenhouse and the dark strain from B. 49119 obtained at Central Cambalache. Monoconidial cultures of the two isolates were prepared in potato dextrose agar (PDA). When these two compatible isolates of $T$. paradoxa were grown together on PDA, fertile perithecia formed in 3 to 7 days at $24^{\circ}$ to $28^{\circ} \mathrm{C}$. in a rather distinct zone where the growths of the two isolates merged (fig. 2). Perithecia were not obtained when the same isolates were grown alone. Without magnification, the perithecia were not evident in culture until the ascospores were extruded from the ostiole

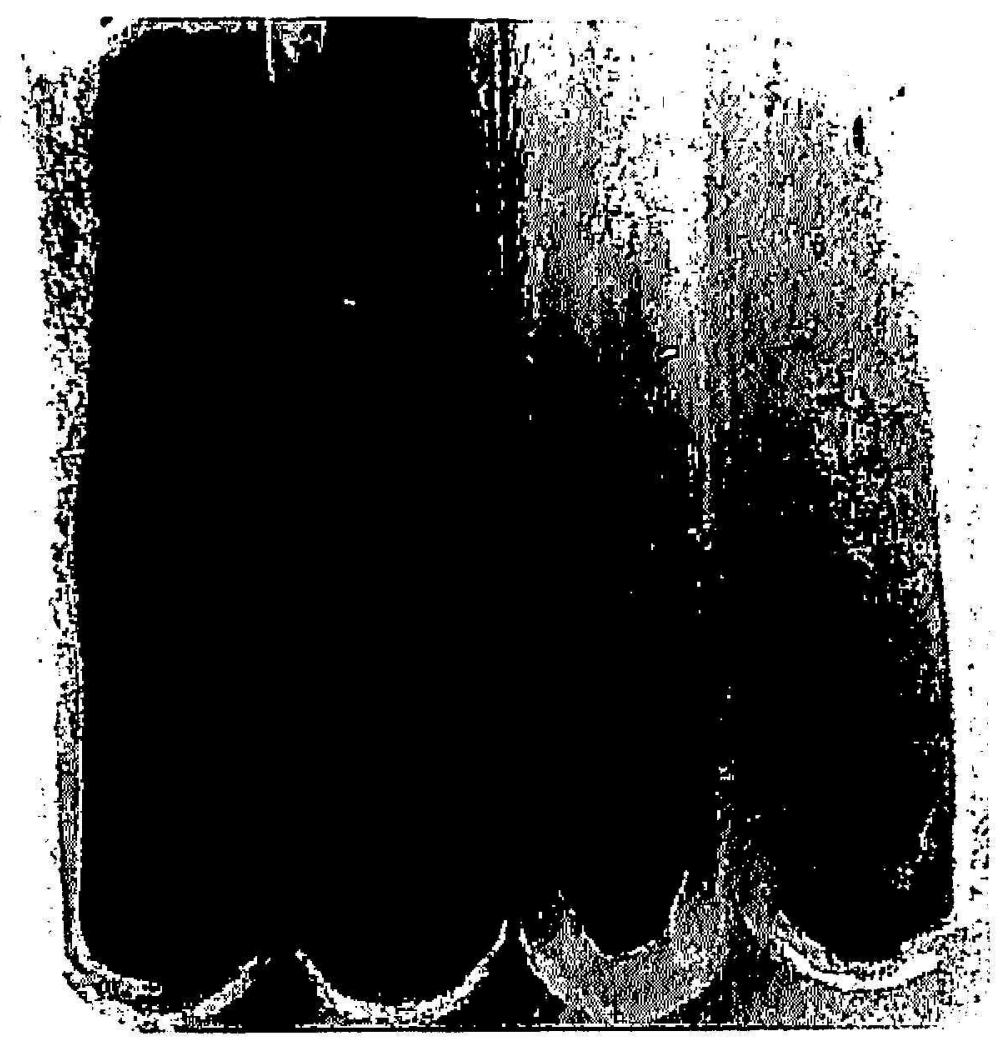

Fig. 1.-Light and dark strains of Thiclaviopsis paradoxa in potato dextrose agar (natural size).

(fig. 3). They then were detected readily with the unaided eye because of the conspicuous, creamy-white, glistening masses of ascospores which collect at the mouth of the perithecial beak. Spore-bearing-asci are difficult to detect.

Perithecia are partially to complotely immersed in the substratum. The bases of the perithecia are pale brown, globose, 250 to $260 \mu$ in diameter and ornamented with numerous, irregularly shaped, knobbed appendages (fig. 4), dark brown to black at the tips. The necks of the perithecia are black, pale brown at the apex, stout, 1150 to $1350 \mu$ long X 40 to $60 \mu$ wide in diameter at the base of the neck and 25 to $30 \mu$ wide at the tip (lig. $\overline{\text { s) }}$. Ostiolar hyphae are hyaline to pale brown, erect, numerous, tapered 
to a point, and measure 102 to $150 \mu$ long $\mathrm{X} 2$ to $3 \mu$ wide (fig. 6). Ascospores are hyaline, ellipsoid, 8 to $11 \mu$ long $\mathrm{X} 4$ to $5 \mu$ wide.

The connection between the perithecial stage and the asexual stage of the fungus was established in the following manner. Ascospore isolations consistently resulted in the recovery of typical $T$. paradoxa cultures. Microscopic examination revealed that the ascospores, upon germination, give rise to characteristic T. paradoxa endoconidia. Furthermore, germina-

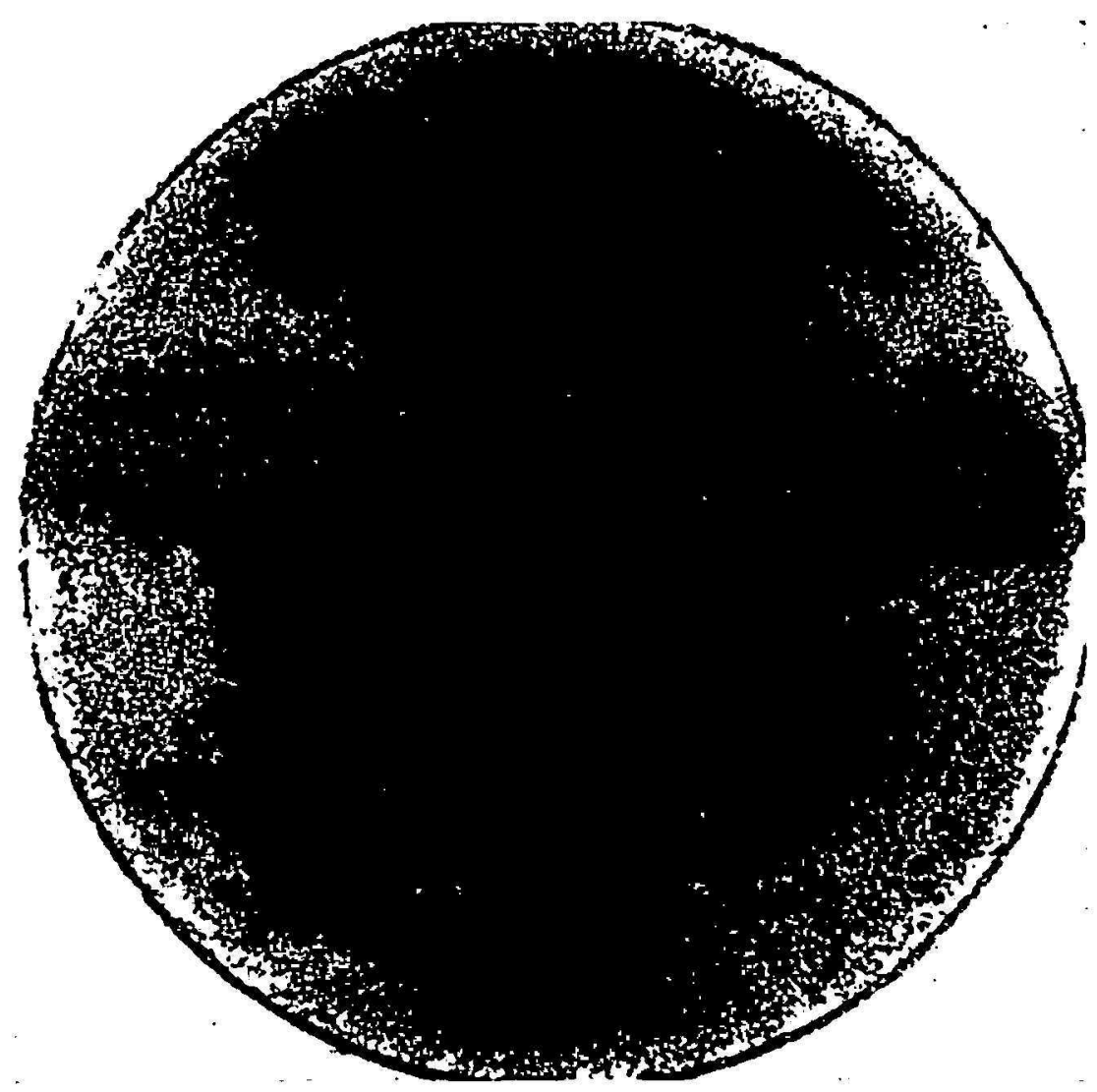

Fig. 2.-Formation of fertile perithecia in potato dextrose agar in a rather distinct zone where the growths of two isolates merged (natural size).

tion of sugarcane varieties, P.R. 980, P.R. 1085, and P.O.J. 2878 were reduced by more than 50 percent when inoculated with conidia and singleconidial isolates of the fungus. In every case, $T$. paradoxa was subsequently isolated.

The cultures of $T$. paradoxa are hyaline at first, with abundant floccose aerial mycelium, rapidly becoming greenish gray. Colonies become dark, greenish black in 10 days. Conidia are borne in chains (fig. 7) and are brown, ovoid to oval, thick-walled, smooth, 16.62 to $19.39 \mu$ long X 8.24 to $11.08 \mu$ wide. Endoconidia are also borne in chains, hyaline to brown, 5.54 to $8.21 \mu$ long $\mathrm{X} 2$ to $3 \mu$ wide. 


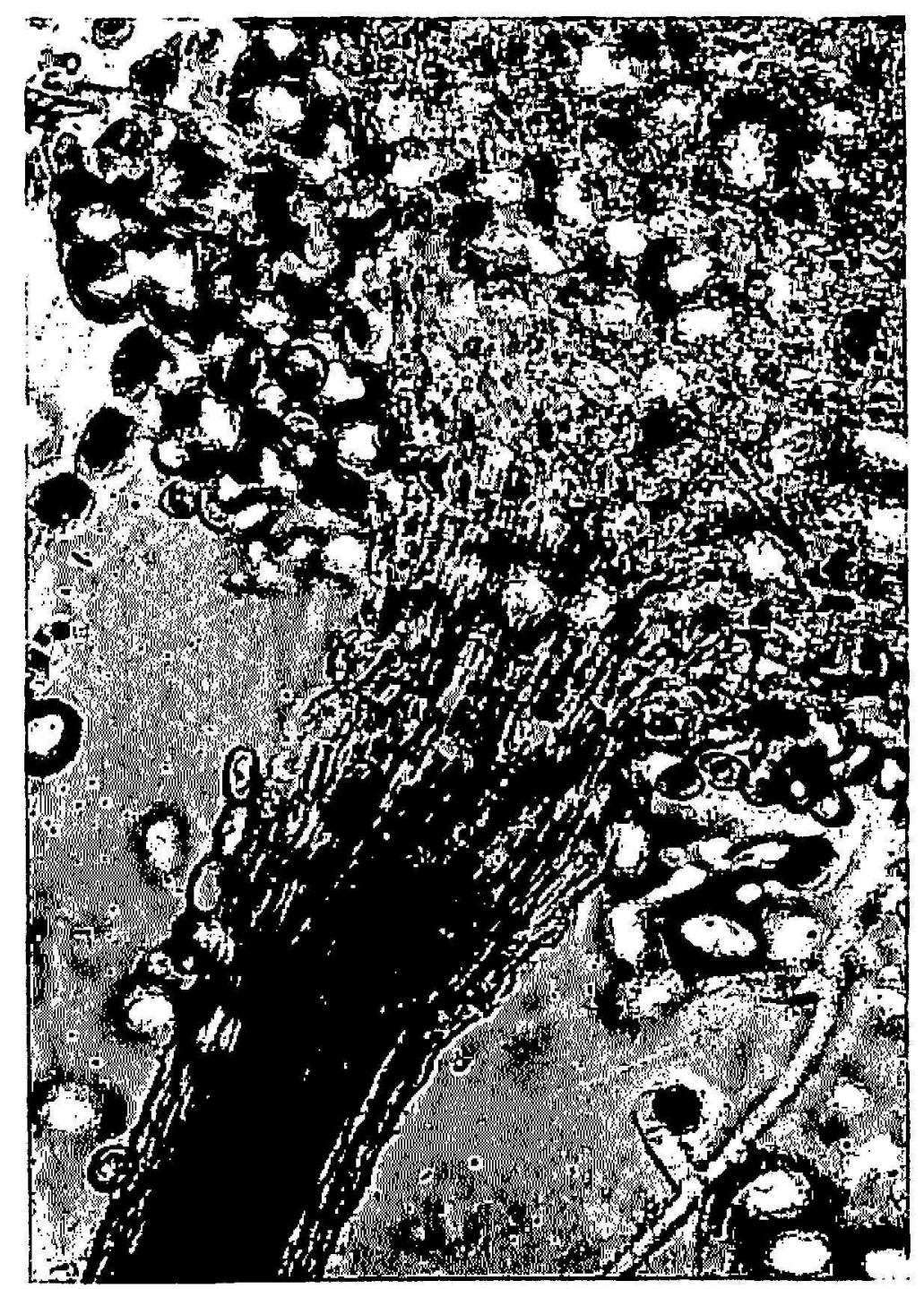

FIc. 3.-Extrusion of ascospores from the ostiole of the perithecium $(1700 \times)$.

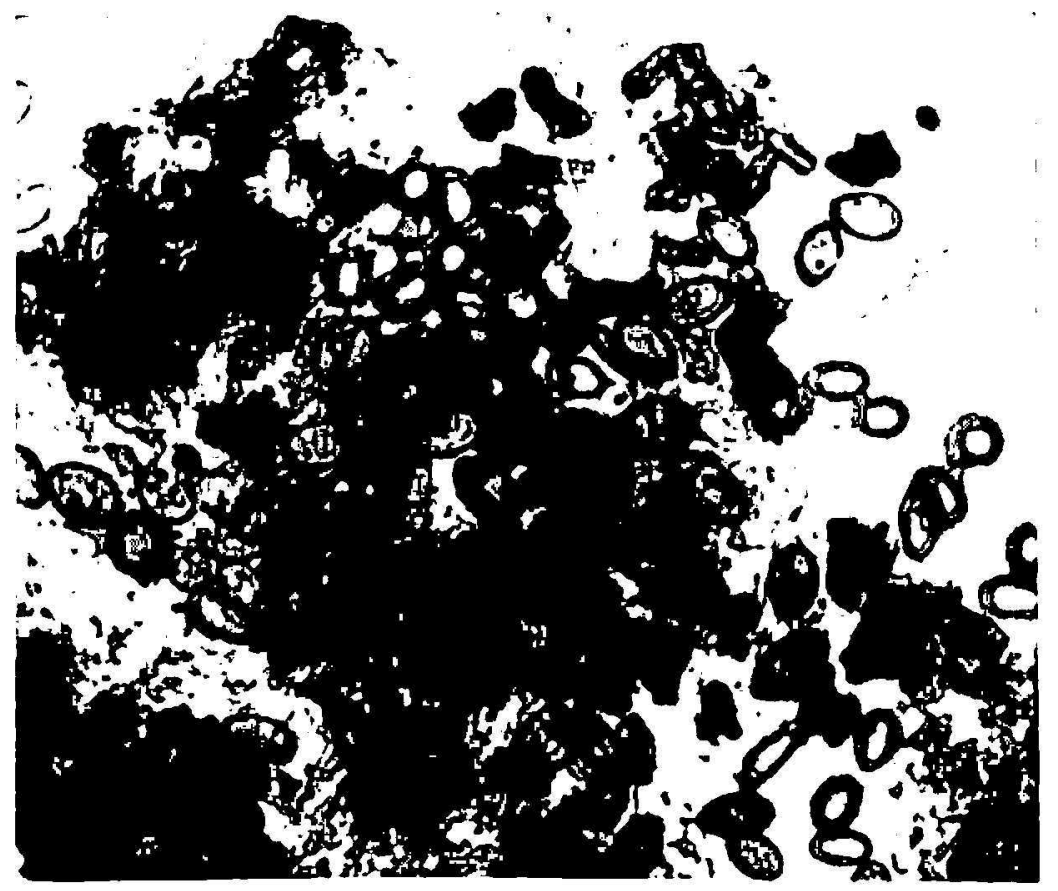

Fra. 4.- Knobbed appendages at the base of the perithecium $(1000 \times)$. 


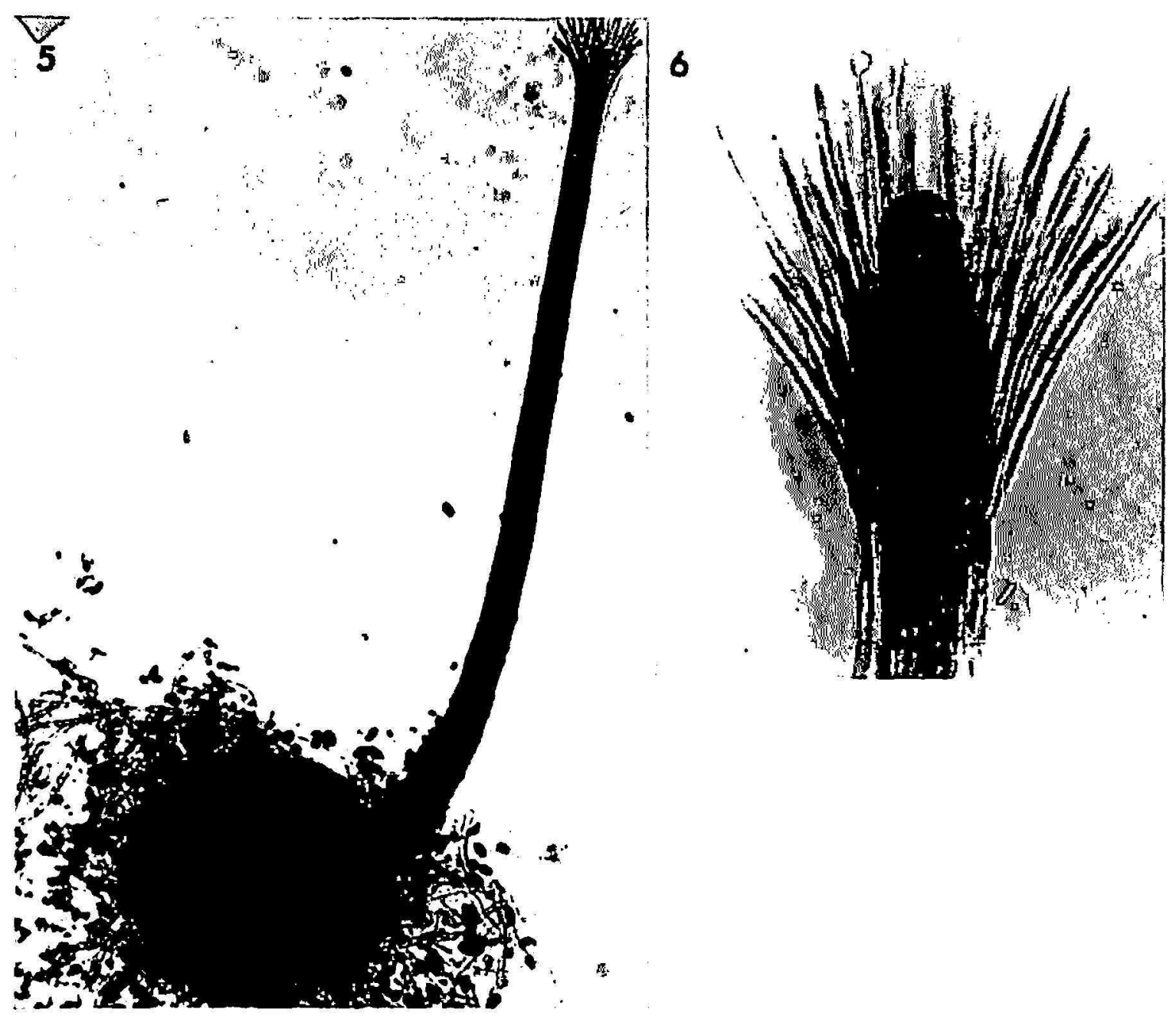

FIG. 5.- Perithecium of T. paradoxa $(750 \times)$.

Fig. 6.- Ostiolar hyphae $(1700 \times)$.

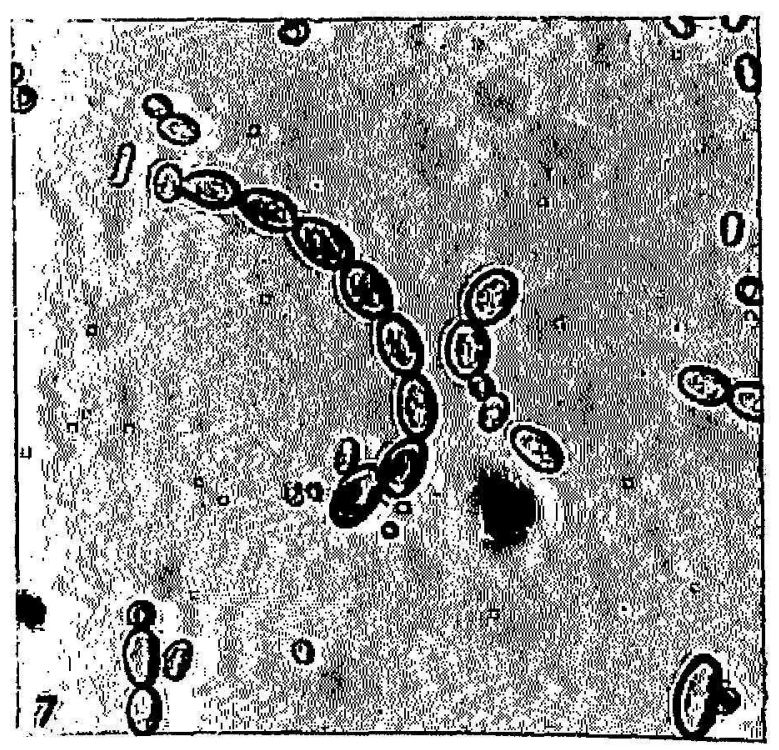

Fia. 7. Marroentidia of 'T. paradoxa in chain $(750 \times)$. 


\section{DISCUSSION AND CONCLUSIONS}

Hunt (8) described 50 species of Ceralocystis in 1956 . He pointed out that only two of them, $C$. radicicola and $C$. paradoxa, have peculiar horn-like appendages on the base of their perithecia. $C$. radicicola can be differentiated readily from $C$. paradox $a$ by the length of the ostiolar hyphae. The ostiolar hyphae of $C$. radicicola measure up to $60 \mu$ long and are blunt at the tips. Those of $C$. paradoxa can measure as much as $150 \mu$ and their tips are pointed. Kuo et al. (10) in 1969 reported the occurrence of Ceralocystis paradoxa on sugarcane. These investigators, however, failed to describe the morphological characteristics of the ostiolar hyphal tips, a very important criterion for use in differentiating $T$. paradoxa from $T$. radicicola. The various lengths of the ostiolar hyphae do not correspond with those given by Hunt ( 8 ) for $T$. paradoxa. A possibility thus exists that, in this particular case, the fungus described by Kuo and co-workers could be T. radicicola. Because the perithecia obtained durng this study produce pointed, cstiolar hyphae more than $100 \mu \mathrm{long}$ it is concluded, therefore, that the specimens represent the sexual stage of $T$. paradoxa, i.e., Ceratocystis paradoxa. It is interesting to note that no perithecia were formed when two monoconidial or ascosporic cultures of the same isolate were placed in an adequate medium. This seems to indicate the existence of two compatibility groups (A and a). Union of compatible isolates is required to trigger the formation of fertile perithecia in vitro. Although compatibility groups have been reported for $C$. radicicola ( 7 ), this same information has not been available for C. pararloxa from sugarcane.

\section{SUMMIRY}

Two strains of Thielaviopsis paradoxa, one light and one dark, were isolated from diseased cuttings of sugarcane in Puerto Rico. Jerithecia were produced when the dark strain was crossed with the light strain in potato dextrose agar medium at $24^{\circ}$ to $28^{\circ} \mathrm{C}$. The perithecia obtained are characteristic of Ceralocystis paradoxa (horn-like appendages on the base of the perithecia and long, pointed ostiolar hyphac). Ascospore isolations consistently resulted in the recovery of typical $T$. paradora culture. No perithecia were produced when cultures of the same isolates were crossed. This constitutes the first report on formation of the sexual stage of $T$. paradoxa from sugarcane in vilro.

\section{RESUMEN}

Dos cepas del hongo Thielaviopsis paradoxa, una de micelio oscuro y otra de micelio claro, fueron aisladas de pedazos de caña enferma. Al cruzarse estas dos cepas en un medio nutritivo de papa azucarado (potato (leatrose agar) ( incubarse a una temperatura de $24^{\circ} \mathrm{C}$. a $28^{\circ} \mathrm{C}$., se obtuvo 
el estado perfecto de este hongo, conocido por Ceratocystis paradoxa. Los peritecios de este hongo se caracterizan porque desarrollan en su base apéndices en forma de cuernos y por poseer hifas ostiolares largas y agudas. Cultivos ascospóricos siempre produjeron el estado imperfecto arriba mencionado. En ningún caso en que se confrontaron cultivos monoconidiales negros o claros, respectivamente, se obtuvo el estado peritecal de este hongo. Este trabajo constituye el primer informe de la formación in vitro del estado perfecto del T. paradoxa en P'uerto Rico.

\section{LITERATURE CITED}

1. Bakshi, B. K., Fungi associated with ambrosia beetles in Great Britain, Brit. Mycol. Soc. Trans. 38: 111-20, 1950.

2. Cook, M. T., Thielaviopsis paradoxa, an important disease of sugarcane, J. Dept. Agr. $16(2)$ : 205, 1032.

3. - The pineapple disease of sugarcane in Puerto Rico, J. Dept. Agr. 17(4): 305-9, 1933.

4. Dade, H. A., Ceratostomella paradoxa, the perfect stage of Thielaviopsis paradoxa (De Seynes), Brit. Mycol. Soc. Trans. 13: 189-92, 1928.

5. Davidson, R. W., Fungi causing stain in logs and lumber in the southern states, including five new species, $J$. Agr. Res. 50: 789-807, 1935.

6. De Seynes, J., Recherches Veg. Infer. 111: 28-34, 1886.

7. El-Ani, A. S., Klotz, L. J., and Wilbur, W. D., Heterothalism, heterokaryosis: and inheritance of brown perithecia in Ceratostomella radicicola, Mycologia 49: 181-7, 1957.

8. Hunt, J., Taxonomy of the genus Ceratocystis, Lloydia 19(1): 1-58, 1956.

9. Johnston, J. R., Selection and treatment of cane seed, Experiment Station of the Sugar Producers Association of Puerto Rico, Bull. No. 6, pp. 1-29, 1913.

10. Kuo, T. K., Chien, M. M., and Li, H. W., Production of the sexual stage of Ceratocystis paradoxa on sugarcane, Int. Soc. Sugarcane Technol. Proc. 13: 1191-6, 1969.

11. Melin, E., and Nannfeldt, J. A., Researches into the blueing of ground woodpulp, Sv. Skogsvardst Tidskr. 32 : 397-616, 1934.

12. Saccardo, P. A., Sylloge Fungorum 10, Supplementum Universale 2: 595, 1892.

13. Von Höhnel, F., Zur Kenntnis einiger Fadenpilze. I. Thielaviopsis paradoxa (1) Seynes) v. Hohn, Hedwigia 49: 295-7, 1904.

14. Went, F. A. F. C., De ananasziekte Van het suikerriet Mededeclingen van het Proefstation voor Suikerriet in "West-Java" te Kagok-Tegal (Reprinted in Arch, voor de Java) Suikerindustrie 1(1): 121-8, 1893. 